\title{
Regular Article \\ Impact of two disinfectants on detachment of Enterococcus faecalis from polythene in aquatic microcosm
}

\author{
C. Lontsi Djimeli ${ }^{1}$, A. Tamsa Arfao, V. Rossi ${ }^{2,3}$, N. Nsulem ${ }^{1}$, V. Raspal ${ }^{4}$, \\ G. Bricheux ${ }^{5}$, M. Nola ${ }^{1, *}$ and T. Sime-Ngando ${ }^{5}$ \\ 1 University of Yaoundé I, Faculty of Sciences, Hydrobiology and Environment Laboratory, P.O. \\ Box 812, Yaoundé, Cameroon \\ 2University of Yaoundé 1, UMI209 UMMISCO, Yaoundé, Cameroon \\ ${ }^{3}$ CIRAD, UPR BSEF, Montpellier, France \\ ${ }^{4}$ C-BIOSENSS-EA 4676, Clermont Université, Université d'Auvergne, Clermont-Ferrand, France \\ ${ }^{5}$ Laboratoire Microorganismes: Génome \& Environnement, UMR CNRS 6023, Université Blaise \\ Pascal, Complexe Scientifique des Cézeaux, 24 avenue des Landais, BP 80026, 63171 Aubière \\ Cedex, France \\ *Corresponding author E-mail: moise.nola@yahoo.com
}

After cell adhesion processes in microcosm, the impact of sodium hypochlorite $(\mathrm{NaOCl})$ and hydrogen peroxide $\left(\mathrm{H}_{2} \mathrm{O}_{2}\right)$ on the detachment of Enterococcus faecalis from polythene fragments immersed in water under stationary and dynamic conditions was assessed. The abundance of planktonic cells was also evaluated. The density of E. faecalis adhered in absence of disinfectant fluctuated between 2 and 4 units (Log CFU/cm²). After living in disinfected water, the density of $E$. faecalis remained adhered to polythene sometimes reached 2 units $\left(\log \mathrm{CFU} / \mathrm{Cm}^{2}\right)$. This highest abundance of cells remained adhered was recorded with cells coming from the lag, exponential and stationary growth phases in water treated with $0.5 \% 0 \mathrm{NaOCl}$. In $\mathrm{H}_{2} \mathrm{O}_{2}$ disinfected water, the highest value was recorded at all cells growth phases with $5 \% \mathrm{H}_{2} \mathrm{O}_{2}$ concentration. Adhered $E$. faecalis cells have been sometimes completely or partially decimated respectively by $\mathrm{NaOCl}$ and $\mathrm{H}_{2} \mathrm{O}_{2}$ treated water. Considering separately each experimental condition, it was noted that increasing the concentration of disinfectant caused a significant decrease $(P \leq 0.01)$ in abundance of cells stay adhered after living in water disinfected by the two disinfectants. Changes in disinfectant concentrations in different experimental conditions had an impact on the detachment of $E$. faecalis cells from the substrates.

Keywords: Disinfectants, Water treatment, E. faecalis, Cell growth phase, Adhesion, Detachment

The distribution network of drinking water is often the scene of many physicochemical and biological reactions resulting from interactions between disinfectants, pipe walls and the free and fixed biomasses. Microbiology of drinking water distribution networks is of great importance because of health risks in the short term and general degradation of water quality or its products (Dukam et al., 1995). Microorganisms are usually found in distribution networks and in storage tanks 
and cause deterioration in the organoleptic water quality (Mouchet et al., 1992; Dogett, 2000).

To remedy this situation, recourse to the use of disinfectants is common. The effectiveness of disinfectants in drinking water distribution network varies from one application to another. While almost $100 \%$ of cells found in planktonic state can be eliminated, the yield is lower on adherent cells (Allion, 2004). Disinfectants used in the treatment of drinking water presents a wide spectrum of action if nothing hinders their activity. They have a preferential action on a type of microorganisms, and if they are not applied in conditions where their lethal activity can be expressed, they favor the selection and even sometimes dangerous proliferation of surviving species. This justifies sometimes the formation of biofilms in water pipes walls despite treatment with disinfectants. Microorganisms in the pipe are either of internal origin (microorganisms that escaped water disinfection processes) or of external origin by water return during intervention work on the network, through cracks caused by aging pipes) (Van der Kooij and Hijnen, 1988).

Quality control analyses of drinking water are based not only on physical, chemical, but also microbiological parameters. The purpose of drinking water treatment is not to produce sterile water, but water that does not present a risk from a public health viewpoint. These analyses showed that Enterococcus faecalis cell is a minority commensal germ of the gastrointestinal and genito-urinary tracts of humans and warm-blooded animals. However, it may become pathogenic in immuno-compromised individuals and elderly persons where it causes more than $10 \%$ of nosocomial infections (Jett et al., 1994; WHO, 2004). Previous work has clearly shown that E. faecalis's adaptability to harsh environments makes it possible to find it in different kinds of waters (Manero and Blanch, 1999). It is an indicator of fecal contamination usually involved in the occurrence of nosocomial infections. It is found in human feces as well as those of warm-blooded animals with concentrations of up to $10^{12}$ cells per gram (Beaupoil et al., 2010). In waste water, they are found at a concentration of $10^{8} \mathrm{CFU} / 1$ (Manero and Blanch, 1999).

In aquatic microcosm containing $E$. faecalis cells and solid particles, the abundances of planktonic E. faecalis cells decreased with incubation periods. This decrease in abundance of cells remained planktonic helped to note that some cells adhere to the support when it is immersed (Hoiby et al., 2010). On this basis, it was thought that the same phenomenon can occur in water distribution networks and cause the formation of biofilms. Then was posed the question, what would be the impact of disinfectants on the physiological and metabolic state of cells detached from substrates?

In a biofilm, microorganisms can develop, and due to their protection in the shell of biofilm, they could potentially become pathogens and pose a public health problem. In fact, studies have shown that bacteria biofilm are frequently observed on the inner walls of the drinking water pipes. These bacteria dropped in water pipes are sources of contamination and health risks to consumers (Allion, 2004; Boutaleb, 2007). In addition, biofilms are escape routes of microorganisms faced with disinfectants.

Although previous studies helped to understand the formation and development of biofilms on rocky substrates and the inside walls of drinking water pipes (Moungang et al., 2013a; Moungang et al., 2013b), the impact of the presence of disinfectants on microorganisms adhered to these walls so far have been paid very little attention. Some authors worked on the physiological and 
metabolic state of the microorganisms and their detachment in the presence of sodium hypochlorite $(\mathrm{NaOCl})$ or hydrogen peroxide $\left(\mathrm{H}_{2} \mathrm{O}_{2}\right)$ (Lontsi Djimeli et al., 2013; Lontsi et al., 2014a). This study aims at evaluating in microcosm conditions with respect to incubation periods and different physiological conditions, the impact of sodium hypochlorite $(\mathrm{NaOCl})$ or hydrogen peroxide $\left(\mathrm{H}_{2} \mathrm{O}_{2}\right)$ on the detachment of $E$. faecalis cells from polythene fragments immersed in water under stationary and dynamic regimes.

\section{Materials and methods \\ Collection and identification of Enterococcus faecalis}

Enterococcus faecalis strain was provided by the Laboratory of Microbiology and Environment of Centre Pasteur of Cameroon. After subculture on plate count agar (PCA), Gram staining was performed on the smear of E. faecalis. Identification tests were performed by standard biochemical methods (Holt et al., 2000; APHA, 2005; Marchal et al., 1991; Rodier, 2009). These identifications revealed that Enterococcus faecalis is oxidase positive generally catalase negative and quickly reduces triphenyl tetrazolium chloride (TTC). It is a facultative anaerobic Gram positive bacterium. The bacterium Enterococcus faecalis was highlighted on Bile-Esculin Azide (BEA) medium whose colonies is translucent and surrounded by a black halo. The black halo surrounding colonies reflects the production of $\mathrm{H}_{2} \mathrm{~S}$ and the hydrolysis of esculin to esculetin that binds with iron (Holt et al., 2000).

\section{Assessment of Enterococcus faecalis cell growth phases}

E. faecalis cell growth phases were evaluated using growth curve (Rubio, 2002). Three replicates of 15 test tubes each containing $10 \mathrm{ml}$ sterile peptone (Biokar) solution was used. Tubes of each set were labelled $\mathrm{t} 0, \mathrm{t} 2, \mathrm{t} 4, \mathrm{t} 6, \mathrm{t} 8, \mathrm{t} 10, \mathrm{t} 12, \mathrm{t} 14, \mathrm{t} 16, \mathrm{t} 18$, t20, t22, t24, t26 and t28. Prior to the experiment, E. faecalis strains previously freezer stored in glycerol vials were defrosted at room temperature in the laboratory. The culture $(300 \mu \mathrm{l})$ was then transferred into 10 $\mathrm{ml}$ of nutrient broth (Oxford) and incubated at $37^{\circ} \mathrm{C}$ for 24 hours and cells latter collected by centrifugation $(8000 \mathrm{rpm}$ for $10 \mathrm{~min}$ at $\left.10^{\circ} \mathrm{C}\right)$ and washed twice with sterile $\mathrm{NaCl}(8.5$ $\mathrm{g} / \mathrm{l})$ solution. The sediment was then diluted in $10 \mathrm{ml}$ of sterile $\mathrm{NaCl}$ solution. After dilution, $100 \mu \mathrm{l}$ of the suspension was added to each of the 15 tubes containing $10 \mathrm{ml}$ of sterilized peptone solution. The cell suspensions in the 3 tubes labelled t0 were immediately analyzed. Those in the tubes labelled $\mathrm{t} 2, \mathrm{t} 4, \mathrm{t} 6 \ldots \mathrm{t} 28$ were incubated for 2 , $4,6 \ldots 28$ hours at $37^{\circ} \mathrm{C}$.

After each incubation period, analyses were carried out using spread plate method on BEA culture medium, incubated for 48 hours at $37^{\circ} \mathrm{C}$. The colony forming units (CFUs) were then counted. Mean CFUs were calculated from the results of the triplicates and Log (CFU) also calculated. The straight Log (CFUs/ml) curve against storage period was plotted and compare to the cell growth curve. The cell growth phases of $E$. faecalis were then determined.

\section{Absorbing substrate used}

The adsorbing substrate used was high dense polythene. It differed from low radical dense polythene and low linear dense polythene by sparsely branched chains of its molecular structure, and its relatively high resistance to shocks, high temperatures and ultraviolet rays (Moungang et al., 2013a; Coeyrehourcq, 2003). It is a plastic piping material obtained directly from the manufacturer and used in drinking water distribution networks. High dense polythene results from polymerization of macromolecules of polyolefin family. This 
polymerization is obtained from gaseous ethylene according to the following equation (Ratner, 1993; Ratner, 1995):

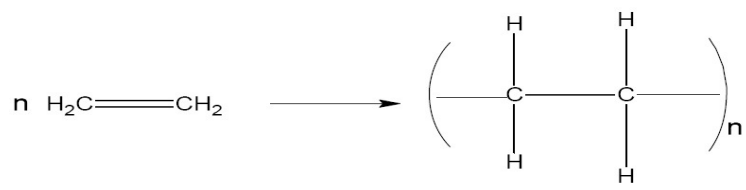

The polythene used in this study is commercialized by Goodfellow SARL (France).

\section{Disinfectants used}

Two disinfectants were used: $\mathrm{NaOCl}$ (Colgate-Palmolive, USA), which belongs to the group of halogen derivatives, and $\mathrm{H}_{2} \mathrm{O}_{2}$ (Gilbert, France) which belongs to the group of oxidants. The ease with which these two disinfectants are generally used for the treatment of drinking water justifies their choice for this study. Concentrations of $\mathrm{NaOCl}$ used ranged from 0.5 to $1.5 \%$ o while Those of $\mathrm{H}_{2} \mathrm{O}_{2}$ oscillated between 5 and 15\%. These concentrations were evaluated by simple method of dilution of crude solution obtained directly from the manufacturer. To count the surviving microorganisms after disinfection, the sterile $\mathrm{NaCl}$ solution was used as a diluent.

\section{Adhesion test of E. faecalis on polythene}

On the basis of previous studies (Lontsi Djimeli et al., 2013; Lontsi Djimeli et al., 2014a; Lontsi Djimeli et al., 2014b), parallelepipedic shaped fragments of polythene with $13.28 \mathrm{~cm}^{2}$ of total surface area suspended to a wire of $0.1 \mathrm{~mm}$ diameter were immersed in triplicate in two sets named A and B. Set A contained four subsets each having three Duran's $250 \mathrm{ml}$ flasks labelled as follows: A1, A1', A1", A2, A2', A2", A3, A3', A3", and A4, A4', A4". Same for set B with labelling as follows: B1, B1', B1"; B2, B2', B2"; B3, B3', B3" and B4, B4', B4". Each flask contained $99 \mathrm{ml}$ of $\mathrm{NaCl}$ solution. Meanwhile, controls were made and coded A01, A02,
A03, A04 and B01, B02, B03, B04 (Noah Ewoti et al., 2011). The whole was then autoclaved. Prior to the experiment, E. faecalis strains previously freezer stored in glycerol vials were defrosted at room temperature. The culture $(300 \mu \mathrm{l})$ was then transferred into 10 $\mathrm{ml}$ of nutrient broth (Oxford) and incubated at $37^{\circ} \mathrm{C}$ for 24 hours and the cells latter collected by centrifugation at $8000 \mathrm{rpm}$ for 10 min at $10^{\circ} \mathrm{C}$, then washed twice with sterile $\mathrm{NaCl}$ solution. The sediment was then diluted in $10 \mathrm{ml} \mathrm{NaCl}$ solution.

After serial dilutions, the initial concentration of bacterium cells (concentration at the initial moment $t=0$ ) in each mother solution was adjusted to 8.77815 units $(\log (\mathrm{CFU} / \mathrm{ml}))$. This was performed by reading the optical density (OD) at $600 \mathrm{~nm}$ using a spectrophotometer (DR 2800) followed by culture on BEA medium (Marchal et al., 1991).

Afterwards, a volume of $1 \mathrm{ml}$ of the suspension was added to $99 \mathrm{ml}$ of sterile physiological water contained in each flask. Erlenmeyer flasks labelled A1, A1', A1", A2, A2', A2", A3, A3', A3", and A4, A4', A4" were incubated with stirring at a speed of 60 revolutions/minutes, using a stirrer (Rotatest brand). Erlenmeyer flasks, labelled B1, B1', B1", B2, B2', B2", B3, B3', B3" and B4, B4', B4" were incubated under static condition. Erlenmeyer flasks labelled A1, A1', A1" and B1, B1', B1" were incubated for $180 \mathrm{~min}$. Those labelled A2, A2', A2" and B2, B2', B2" B1" were incubated for 360 minutes. Erlenmeyer flasks labelled A3, A3', A3" and B3, B3', B3" were incubated for 540 minutes. Those labelled A4, A4', A4" and B4, B4', B4" were incubated for $720 \mathrm{~min}$. All these incubations were made at room temperature in the laboratory $\left(25 \pm 1^{\circ} \mathrm{C}\right)$.

\section{Determination of abundance of E. faecalis cell remained planktonic}

E. faecalis cell adhesion to polythene was performed in sterile physiological water 
contained in the Erlenmeyer flasks. This led to assess the abundance of E. faecalis cells remained planktonic at the initial time (T0) and densities of cells remained planktonic after 180, 360, 540 and 720 minutes of incubation. The collection and enumeration of cells remained planktonic were carried out after removal of each polythene fragment from Erlenmeyer by monitoring the cells growth on BEA medium followed by incubation at $37^{\circ} \mathrm{C}$ for 24 to 48 hours.

Impact of $\mathrm{NaOCl}$ and $\mathrm{H}_{2} \mathrm{O}_{2}$ on the detachment of $E$. faecalis cells from the polythene fragments

The contaminated substrates allowed to highlight the impact of $\mathrm{NaOCl}$ and $\mathrm{H}_{2} \mathrm{O}_{2}$ concentrations on cells detachment for 25 to 30 minutes. The disinfecting effect was stopped by introducing substrates in $10 \mathrm{ml}$ of sterile saline. Cells detachment and appreciation of the reduction of the bacteria load were assessed after culture of surviving bacteria.

Depending on the type of disinfectant tested, the fragments removed from Erlenmeyer flasks A1, A2, A3, A4, B1, B2, B3 and $\mathrm{B} 4$ after 30 minutes from water treatment with $0.5 \%$ o $\mathrm{NaOCl}$ or $5 \% \quad \mathrm{H}_{2} \mathrm{O}_{2}$. The fragments removed from flasks A1', A2', A3', A4', B1', B2', B3' and B4' after 30 minutes living in water disinfected with $1 \% \mathrm{NaOCl}$ or $10 \%$ o $\mathrm{H}_{2} \mathrm{O}_{2}$. Similarly, those removed from Erlenmeyer flasks A1", A2', A3', A4", B1', B2', B3" and B4" after 30 minutes living in water treated $1.5 \%$ o $\mathrm{NaOCl}$ or $15 \% \mathrm{H}_{2} \mathrm{O}_{2}$. After this disinfection test of 30 minutes at room temperature under static condition, each fragment was released and drained sterile and introduced into $10 \mathrm{ml}$ sterilized $\mathrm{NaCl}$ solution.

The unhooking of adherent cells was performed by vortex agitation at increasing speeds for 30 seconds in three consecutive series of $10 \mathrm{ml}$ sterilized $\mathrm{NaCl}$ solution. This technique allowed the unhooking of maximum adhered cells (Dukam et al., 1995; Noah Ewoti et al., 2011). The total volume of the suspension containing unhooked $E$. faecalis cells was $30 \mathrm{ml}$. Collection and numbering of unhooked cells were performed using the spread plate method on BEA medium, followed by the incubation in Petri dishes at $37^{\circ} \mathrm{C}$ for 24 to 48 hours. The disinfectant was not evaluated after incubation.

\section{Data analysis}

Variations in abundance of planktonic and adhered $E$. faecalis cells in each experimental condition were illustrated by semi-Logarithmic curves. Standard deviations were not considered because the curves were too close. Spearman " $r$ " correlation test was used to assess the degree of relation between the abundance of adhered E. faecalis cells and incubation periods for each concentration of disinfectant on one hand, and between the abundance of the cells remained adhered and concentrations of disinfectants for each incubation period and for each cell growth phase on the other hand. To compare the mean abundance of E. faecalis remained adhered from one experimental condition to another, Kruskal-Wallis $\mathrm{H}$ test and Mann-Whitney $U$ test were used using the statistical software package SPSS 17.0. A $P$-value of 0.05 was assumed to be statistically significant.

\section{Results and discussion Enterococcus faecalis growth curve}

The growth of E. faecalis in non renewed sterile tryptone liquid medium (Biokar) exhibited a hyperbolic curve of 4 phases (Fig. 1): a lag growth phase of 2 hours, an exponential growth phase from the $5^{\text {th }}$ to the $11^{\text {th }}$ hour of incubation, a stationary growth phase of 12 hours and a decline growth phase which began from the $22^{\text {nd }}$ hour of incubation (Fig. 1). Bacterial growth is an orderly increment of all the components of 
the bacterium (Rubio, 2002). It leads to an increase in the number of bacteria. During growth, there is, on one hand, a depletion of nutrients in the culture medium and, on the other hand, an enrichment of products of metabolism, that are toxic. During the lag growth phase, the growth rate is nil. Bacteria adapt and synthesize the enzymes necessary to metabolize new substrates. The exponential growth phase corresponds to the period of nutrient utilization and duplication of cell number. The stationary growth phase is the period when the growth rate becomes nil. In fact, the bacteria multiply compensating those who die. The decline growth phase is the time when all food resources are exhausted. There is accumulation of toxic metabolites. There is a decrease of viable organisms and an occurring of cell lysis by the action of endogenous proteolytic enzymes. However, there is a persistant growth leading to the release of substances during lysis (cryptic growth) (Rubio, 2002).

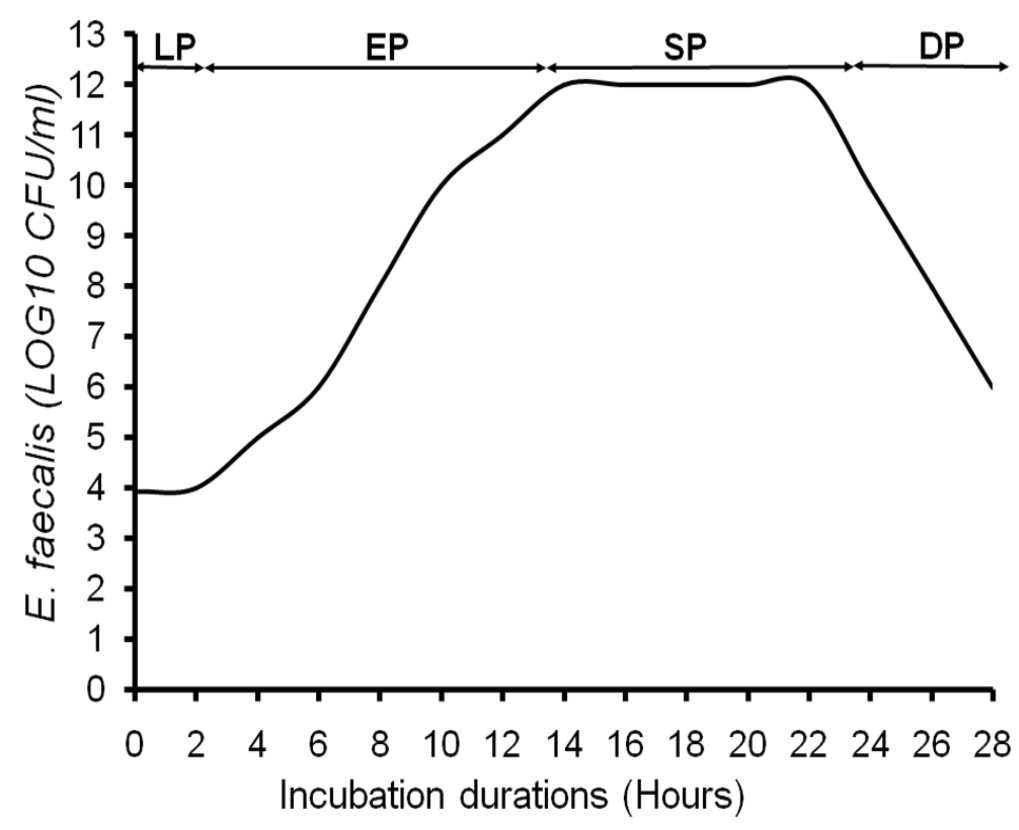

Figure 1. Growth curve of E. faecalis (LP: Lag phase; EP: Exponential growth phase; SP: Stationary growth phase; DP: Decline growth phase).

Assessment of E. faecalis cell abundance remained planktonic

The densities of E. faecalis cells remained planktonic ranged from 8.77776 to 8.77807 units $\left(\log \mathrm{CFU} / \mathrm{Cm}^{2}\right)$. The maximum value was recorded after 180 minutes with cells coming from the lag growth phase. The minimum value was registered after 720 minutes with cells coming from the stationary growth phase (Fig. 2). When considering either under stationary or dynamic regime, a relative decrease was noted with abundance of $E$. faecalis cells remained planktonic at each incubation period and each cell growth phase. This decrease in abundance of cells remained planktonic revealed that, some cells adhered to polythene fragment follow the reversible and irreversible adhesion mechanisms. According to Pouneh (2009), bacterial adhesion to supports takes place in two main stages: adherence and adhesion, which 
respectively correspond to a reversible adhesion and an irreversible fixation of bacteria. The reversible adhesion is usually non-specific and short term (5-10 hours) (Gauthier and Isoard, 1989). The irreversible adhesion is a step slower than the former. The irreversibility of adhesion is due to the fact that the bacterium secretes a matrix of exopolymers forming an envelope around it called glycocalyx, and other specific molecules (adhesins) that allow it to consolidate its adhesion to the substrate (Rubio, 2002).
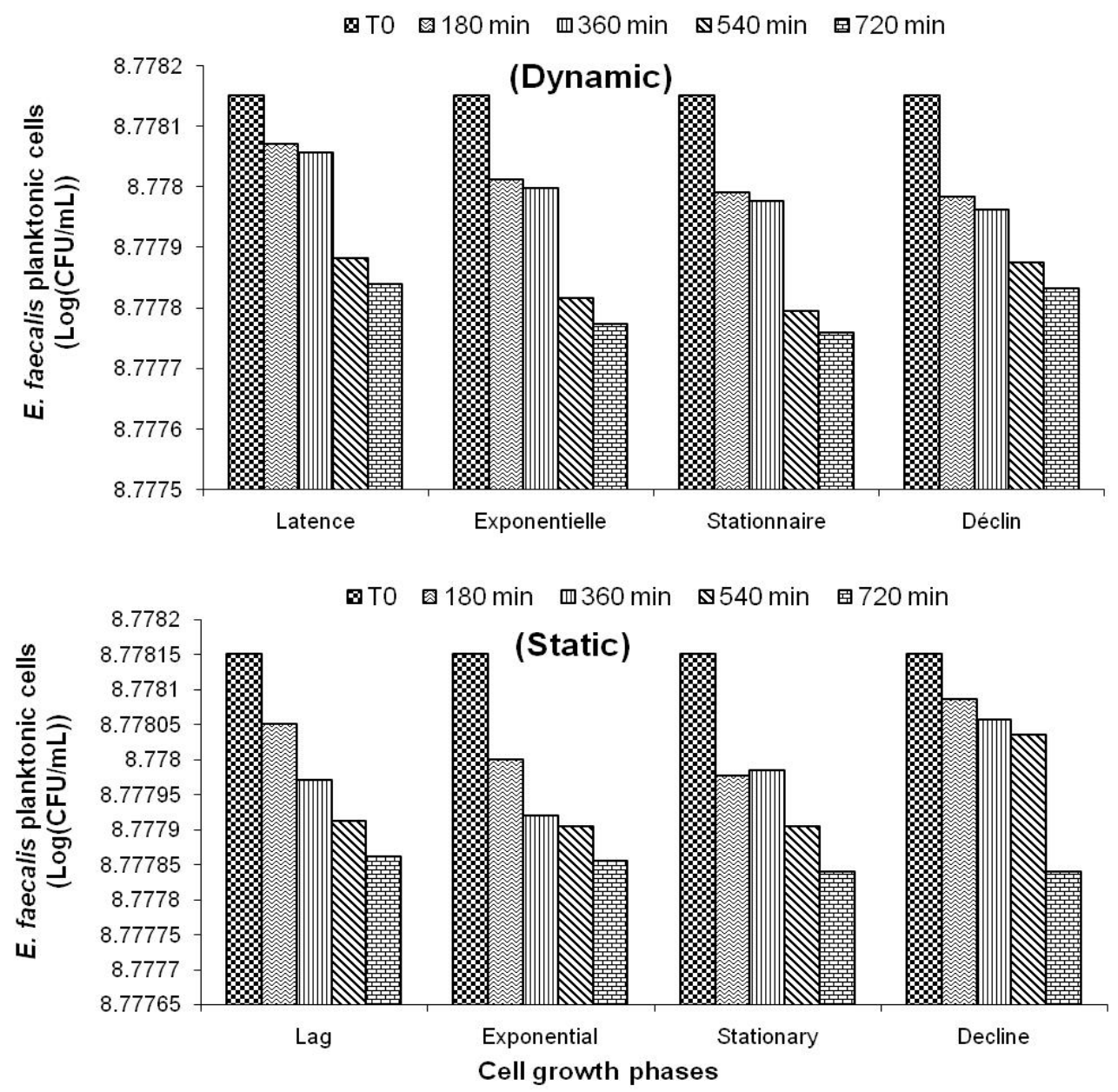

Figure 2. Temporal variations of abundance of E. faecalis cells remained planktonic at each cell growth phase under static and dynamic conditions.

Impact of $\mathrm{NaOCl}$ and $\mathrm{H}_{2} \mathrm{O}_{2}$ on the detachment of $E$. faecalis cells adhered to polythene

After the adhesion process of $E$. faecalis, the impact of these disinfectants on the detachment of cells remained adhered to polythene was assessed by allowing to stay for the specify periods, the contaminated materials in water disinfected with increasing of $\mathrm{NaOCl}$ and $\mathrm{H}_{2} \mathrm{O}_{2}$ concentrations. After the adhesion test, followed by the disinfection test, some E. faecalis cells remained adhered to the polythene fragments. These cells remained adhered were themed "cells remained". 

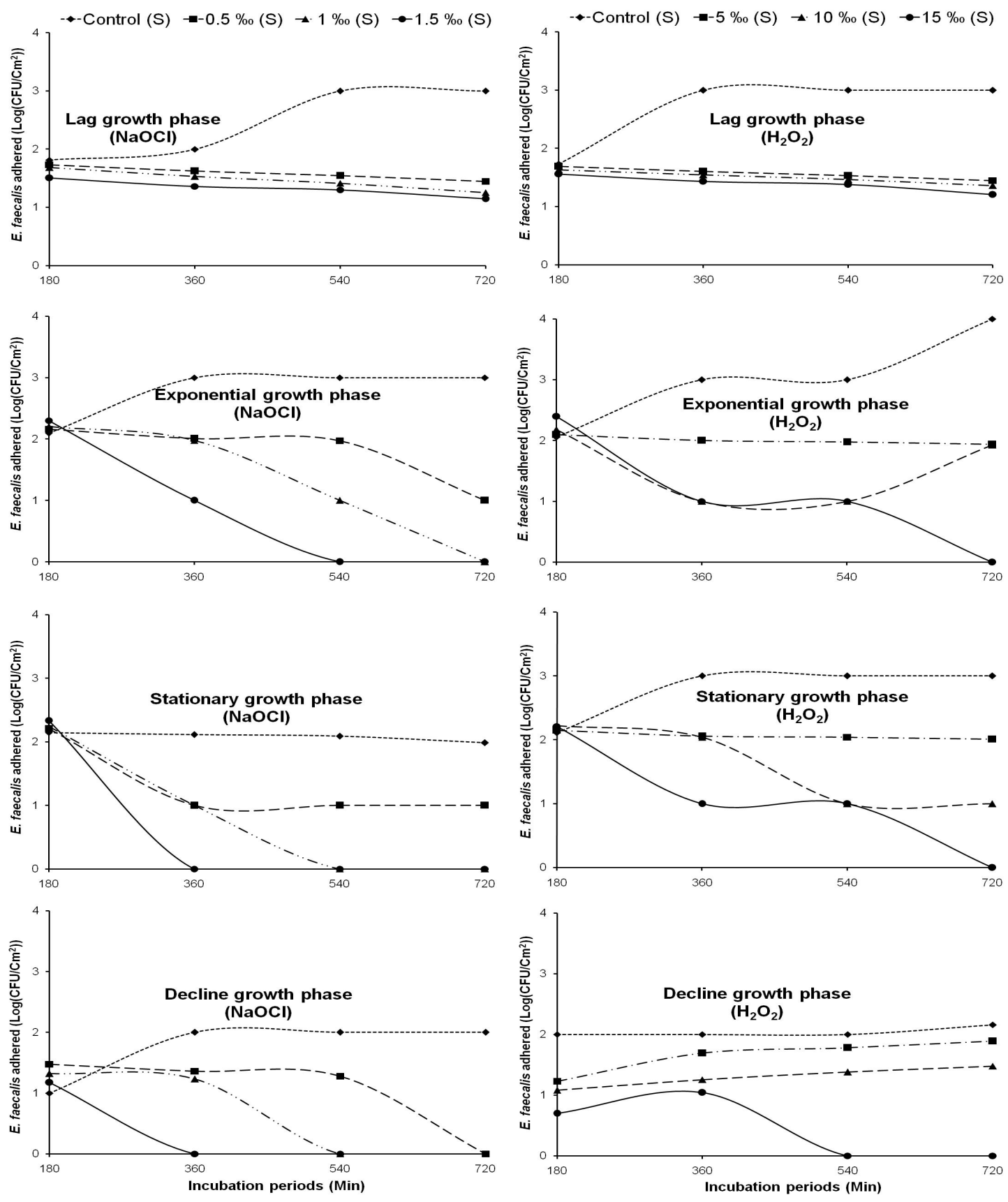

Figure 3. Temporal evolution of E. faecalis cells remained adhered to polythene under static condition in $\mathrm{NaOCl}$ and $\mathrm{H}_{2} \mathrm{O}_{2}$ treated water.

When using $\mathrm{NaOCl}$ under static condition, the density of E. faecalis cells remained adhered to polythene varied with different cells growth phases and different disinfectant concentrations (Fig. 3). The abundance of adhered E. faecalis cells in the absence of disinfectant ranged from 1 to 3 units ( $\log$ $\mathrm{CFU} / \mathrm{Cm}^{2}$ ). The lowest value was recorded with cells coming from decline cell growth phase after 180 minutes incubation period. 
The highest value was registered with cells harvested from lag and exponential growth phases after 540 and 720 minutes incubation durations. In water treated with $\mathrm{NaOCl}$, the abundance of cells remained adhered often reached 2 units $\left(\mathrm{Log} \mathrm{CFU} / \mathrm{Cm}^{2}\right)$. This highest abundance of $E$. faecalis cells remained
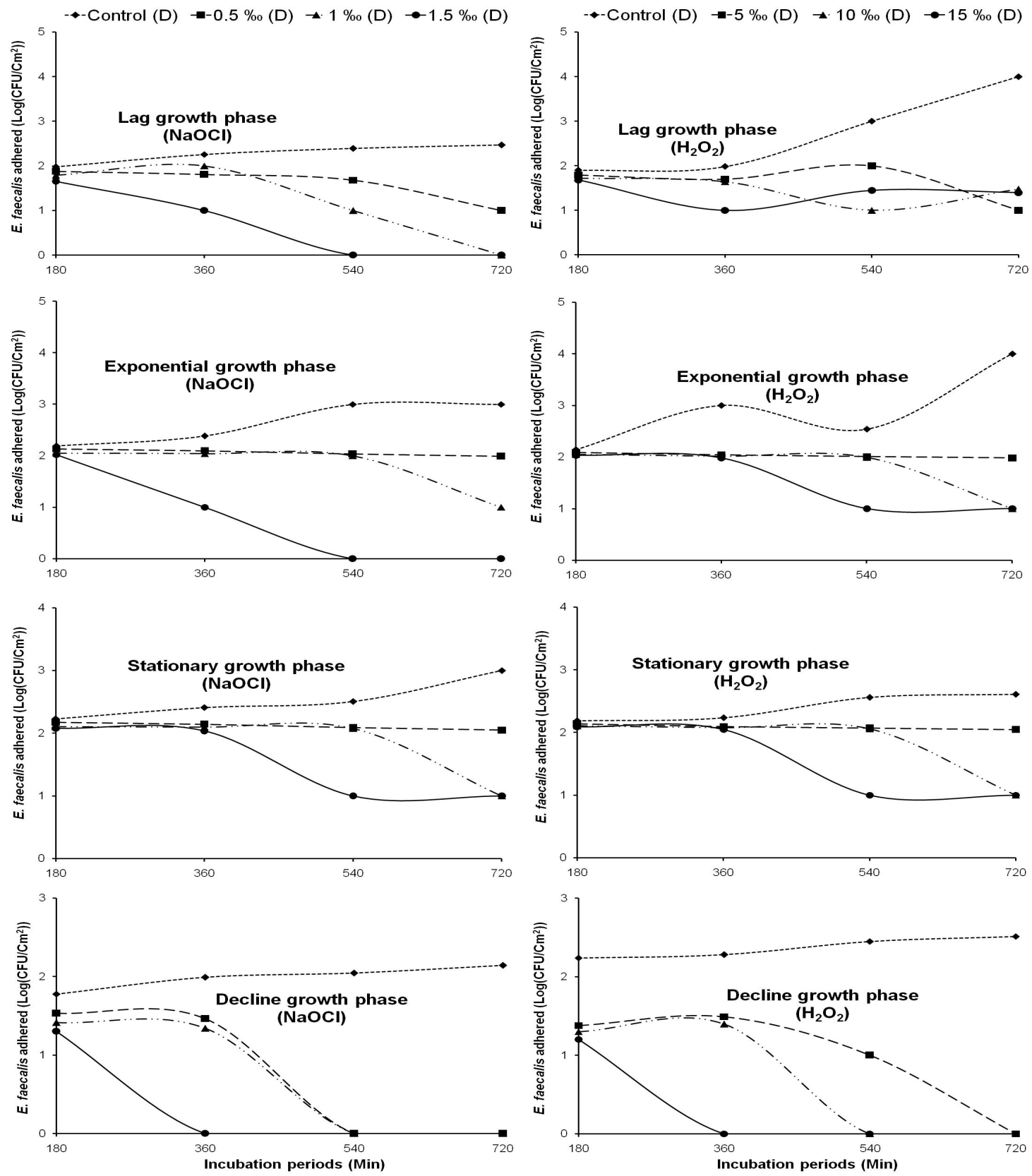

Figure 4. Temporal evolution of E. faecalis cells remained adhered to polythene under dynamic condition in $\mathrm{NaOCl}$ and $\mathrm{H}_{2} \mathrm{O}_{2}$ treated water. 
Table 1. Spearman " $r$ " Correlation coefficients between abundance of E. faecalis cells remained adhered to polythene and incubation periods for each concentration of disinfectant and each experimental condition

\begin{tabular}{|c|c|c|c|c|c|c|}
\hline \multirow{3}{*}{$\begin{array}{l}\text { Experimental } \\
\text { conditions }\end{array}$} & \multicolumn{6}{|c|}{ Disinfectants and concentrations } \\
\hline & \multicolumn{3}{|c|}{$\mathrm{NaOCl}$} & \multicolumn{3}{|c|}{$\mathrm{H}_{2} \mathrm{O}_{2}$} \\
\hline & $0.5 \%$ & $1 \%$ o & $1.5 \%$ & $5 \%$ & $10 \%$ & $15 \%$ \\
\hline Static & $-0.601^{*}$ & $-0.517^{*}$ & -0.461 & $-0.895^{\star *}$ & $-0.889 * *$ & $-0.778^{* *}$ \\
\hline Dynamic & $-0.759 * *$ & $-0.534^{*}$ & -0.479 & $-0.880^{\star *}$ & $-0.862^{* *}$ & $-0.837^{* *}$ \\
\hline
\end{tabular}

** $: \mathrm{P} \leq 0.01 *: \mathrm{P} \leq 0.05 \mathrm{df}=15$

Table 2. Spearman " $r$ " Correlation coefficients between cells abundance of E. faecalis remained adhered to polythene and disinfectant concentrations in each incubation period and each experimental condition.

\begin{tabular}{|c|c|c|c|c|c|c|c|c|}
\hline \multirow{3}{*}{$\begin{array}{l}\text { Experimental } \\
\text { conditions }\end{array}$} & \multicolumn{8}{|c|}{ Disinfectants and incubation durations } \\
\hline & \multicolumn{4}{|c|}{$\mathrm{NaOCl}$} & \multicolumn{4}{|c|}{$\mathrm{H}_{2} \mathrm{O}_{2}$} \\
\hline & $180 \mathrm{~min}$ & $360 \mathrm{~min}$ & $540 \mathrm{~min}$ & $720 \mathrm{~min}$ & $180 \mathrm{~min}$ & $360 \mathrm{~min}$ & $540 \mathrm{~min}$ & $720 \mathrm{~min}$ \\
\hline Static & -0.415 & -0.444 & -0.415 & -0.503 & $-0.816^{* *}$ & $-0.712^{* *}$ & $-0.742^{* *}$ & $-0.711^{\star *}$ \\
\hline Dynamic & -0.401 & -0.490 & -0.562 & $-0.578^{*}$ & $-0.867^{* *}$ & $-0.892^{* *}$ & $-0.890 * *$ & $-0.857^{* *}$ \\
\hline
\end{tabular}

Table 3. Comparison between mean abundance remained adhered on polythene in disinfected water and different cell growth phases.

\begin{tabular}{lcccc}
\hline Disinfectants & \multicolumn{4}{c}{ Cell growth phases } \\
\cline { 2 - 5 } & \multicolumn{1}{c}{ Lag } & Exponential & Stationary & Decline \\
\hline $\mathrm{NaOCl}$ & $\mathrm{P}=0.019^{*}$ & $\mathrm{P}=0.042^{*}$ & $\mathrm{P}=0.124$ & $\mathrm{P}=0.008^{*}$ \\
$\mathrm{H}_{2} \mathrm{O}_{2}$ & $\mathrm{P}=0.008^{*}$ & $\mathrm{P}=0.019^{*}$ & $\mathrm{P}=0.021^{*}$ & $\mathrm{P}=0.017^{*}$ \\
$*: \mathrm{P} \leq 0.05$ & $\mathrm{df}=22$ & & &
\end{tabular}

Under dynamic condition, the abundance of $E$. faecalis cells remained adhered to polythene also varied with different cells growth phases and different concentrations of $\mathrm{NaOCl}$ (Fig. 4). The density of $E$. faecalis adhered in absence of disinfectant under dynamic condition fluctuated between 2 and 4 units $\left(\mathrm{Log}\left(\mathrm{CFU} / \mathrm{cm}^{2}\right)\right)$. The highest value was recorded with cells harvested from lag and exponential growth phases after 720 minutes incubation duration. The lowest value was registered with cells coming from all cell growth phases after 180 minutes incubation period. The abundance of $E$. faecalis remained adhered to polythene in $\mathrm{NaOCl}$ treated water sometimes reached 2 units $\left(\log \mathrm{CFU} / \mathrm{Cm}^{2}\right)$. The highest value was registered at all cells growth phases after living in water disinfected with $0.5 \%$ NaOCl. Under dynamic condition, adhered $E$. faecalis cell has been sometimes completely decimated by $\mathrm{NaOCl}$ treated water (Fig. 4).

It was observed that under dynamic condition, the abundance of E. faecalis cells remained adhered to polythene was relatively higher than that observed under static condition. In general, when the concentration of $\mathrm{NaOCl}$ in water increased, the abundance of $E$. faecalis cells remained adhered decreased with time (Figs 3 and 4).

When using $\mathrm{H}_{2} \mathrm{O}_{2}$ and under static condition, it is clear from figures 3 and 4 that the cells of E. faecalis remained adhered to polythene generally varied with different cell growth phases and concentrations of $\mathrm{H}_{2} \mathrm{O}_{2}$. The density of $E$. faecalis adhered in absence of $\mathrm{H}_{2} \mathrm{O}_{2}$ under static condition ranged from 2 
to 4 units $\left(\mathrm{Log} \mathrm{CFU} / \mathrm{Cm}^{2}\right)$. The highest value was recorded with cells coming from exponential cell growth phase after 720 minutes incubation duration. The lowest value was registered with cells coming from all cell growth phases after 180 and 360 minutes incubation periods. The abundance of $E$. faecalis remained adhered to polythene in $\mathrm{H}_{2} \mathrm{O}_{2}$ disinfected water often reached 2 units $\left(\mathrm{Log} \mathrm{CFU} / \mathrm{Cm}^{2}\right)$. Under static condition, adhered E. faecalis cell has been sometimes partially decimated by $\mathrm{H}_{2} \mathrm{O}_{2}$ treated water. The highest value was recorded at all cells growth phases in water disinfected with $5 \%$ $\mathrm{H}_{2} \mathrm{O}_{2}$ after 360, 540 and 720 minutes incubation periods (Fig. 3).

Under dynamic condition, the density of adhered E. faecalis cells in the absence of $\mathrm{H}_{2} \mathrm{O}_{2}$ oscillated between 2 and 4 units (Log $\mathrm{CFU} / \mathrm{Cm}^{2}$ ). The highest value was registered with cells harvested from lag and exponential growth phases after 720 minutes incubation duration. The lowest value was recorded with cells coming from all cell growth phases after 180 minutes incubation period. The abundance of cells remained adhered to polythene often reached 2 units ( $\log$ $\mathrm{CFU} / \mathrm{cm}^{2}$ ) in $\mathrm{H}_{2} \mathrm{O}_{2}$ treated water. This value was recorded with cells coming from the lag, exponential and stationary growth phases in water treated with 5 and $10 \% \mathrm{H}_{2} \mathrm{O}_{2}$. Adhered E. faecalis cell has been sometimes partially decimated by $\mathrm{H}_{2} \mathrm{O}_{2}$ treated water under dynamic condition (Fig. 4).

The abundance of E. faecalis cells remained adhered to polythene was generally relatively more important under dynamic condition than under static condition. In most cases, the abundance of E. faecalis cells remained adhered to polythene decreased with time as the concentration of $\mathrm{H}_{2} \mathrm{O}_{2}$ increased in water (Figs 3 and 4).

Detachment of adhered E. faecalis cells from polythene depends on the incubation period, cell growth phase and concentrations of disinfectant. Increasing the duration of the disinfection process in most cases leads to a significant decrease in abundance of $E$. faecalis cells remained adhered to polythene in each solution treated with $\mathrm{NaOCl}$ or $\mathrm{H}_{2} \mathrm{O}_{2}$ under static and dynamic conditions. In fact, $E$. faecalis cells fixed on a substrate and produce extracellular polymers have an altered phenotype compared to corresponding remaining planktonic cells, particularly with regards to growth, gene transcription, protein production and intercellular interaction (Hoiby et al., 2010). In addition, the reduction of penetration of molecules including disinfectants due to changes in cell density and production of exopolysaccharides, slow growth, modulation of stress response and other metabolic processes are the main causes of the reduction of the sensitivity of cells adhered to disinfectants (Keren et al., 2004).

It is noted that the abundance of $E$. faecalis remained adhered in all cell growth phases was relatively lower in general, in the presence of $\mathrm{NaOCl}$ or $\mathrm{H}_{2} \mathrm{O}_{2}$ than in the absence of these two disinfectants, whether under static or dynamic conditions. $\mathrm{NaOCl}$ is the best chlorine molecule used as a disinfectant. Its biocidal efficacy is based on the penetration of the chemical substance and its action on the essential oxidative enzymes of the cell (Lomander et al., 2004).

\section{Relationships amongst the considered parameters}

The Spearman " $r$ " correlation coefficient between abundance of adhered cells and incubation periods for each concentration of disinfectant and experimental condition was calculated and are presented in Table 1 . It is noted that increasing the duration of adhesion caused a significant decrease of cell abundance remained adhered to polythene in each disinfectant solution $(\mathrm{P} \leq 0.01)$.

Compared to low concentrations, increasing the concentration of disinfectants caused a significant decrease $(\mathrm{P} \leq 0.01)$ in cells 
abundance of $E$. faecalis remained adhered after a stay in water disinfected with $\mathrm{NaOCl}$ and $\mathrm{H}_{2} \mathrm{O}_{2}$. This resulted in a relative increase in the efficacy of $\mathrm{NaOCl}$ and $\mathrm{H}_{2} \mathrm{O}_{2}$ on $E$. faecalis cells remained adhered to polythene as the disinfectants concentration increased in the medium (Table 2). Indeed, biofilms are a protection means for growth, allowing microorganisms to survive in hostile environments and conferring reduced susceptibility to dehydration, antibiotics and disinfectants. The cells attached to surfaces (supports) have reduced sensitivity to disinfectants compared to cells remained planktonic (Smith and Hunter, 2008). A biofilm can develop within hours and thus allow bacteria therein to become resistant to external agents causing contamination (Beech and Coutinho, 2003; Beech and Sunner, 2004). In addition, adhered cells often induce increased resistance to disinfecting agents compared to planktonic cells (Smith and Hunter, 2008; Parot, 2007). Prolonged contact between cells and the support leads to the secretion in situ of proteins which enhance their interactions. These interactions are thereafter inhibited by the disinfectants (Guillemot, 2006). On the other hand, for each incubation period, the action of $\mathrm{NaOCl}$ and $\mathrm{H}_{2} \mathrm{O}_{2}$ on $E$. faecalis cells remained adhered to polythene increased significantly $(\mathrm{P} \leq 0.01)$. The action of these disinfectants is explained by the action of disinfectant molecules that are chemically more reactive on biofilms (Ntsama et al., 1995). Furthermore, this variation of reaction of $E$. faecalis cells in the face of disinfectants may be related to changes in their surface following a change in their cell growth phase (Briandet et al., 1999).

Table 3 revealed a significant difference $(P \leq 0.05)$ between the mean abundance of $E$. faecalis remained adhered on polythene after a stay in treated water and the different concentrations of $\mathrm{NaOCl}$ at different cell growth phases. This difference is due to a nutritional limitation experimented with these cells and which is the cause of variation in the growth rate (Yasuda et al., 1993; Yasuda et al., 1994; Suci et al., 1994). Similarly, at each cell growth phase, there was a significant difference $(P \leq 0.05)$ between the mean abundance of $E$. faecalis cells remained adhered after a stay in waters treated with different concentrations of $\mathrm{NaOCl}$ (Table 3). The effectiveness of any disinfection method depends on biotic factors such as physiological state and the intrinsic microbial resistance to lethal agents (Parot, 2007). E. faecalis cells remained adhered to polythene under dynamic condition are more sensitive to $\mathrm{NaOCl}$ and $\mathrm{H}_{2} \mathrm{O}_{2}$ than those remained adhered under static condition. According to (Klausen et al., 2006) this could be explained by the structure of cells that remained adhered which depends on a hydrodynamic regime. Moreover, $\mathrm{NaOCl}$ and $\mathrm{H}_{2} \mathrm{O}_{2}$ act on several components of the bacteria and biofilm while other disinfectants (chlorhexidine) act only on the cell wall (Leung et al., 2012).

\section{Conclusion}

This study focused on assessing in microcosm condition the impact of $\mathrm{NaOCl}$ and $\mathrm{H}_{2} \mathrm{O}_{2}$ on the detachment of E. faecalis cells adhered to polythene fragments immersed in water under static and dynamic conditions. It appeared from this study that, after the adhesion process, E. faecalis cells remained adhered to polythene fragments after a stay in water disinfected with antimicrobial substances. The abundance of E. faecalis cells remained adhered to polythene revealed temporal variations. These changes are related to biotic and abiotic properties of $E$. faecalis cells and polythene.

Considering separately each experimental condition, it was noted that increasing the duration of the adhesion process causes a significant decrease of abundance of $E$. faecalis cells remained adhered to polythene in each solution treated 
with $\mathrm{NaOCl}$ or $\mathrm{H}_{2} \mathrm{O}_{2}$. Similarly, increasing the concentration of disinfectants caused a significant decrease in abundance of $E$. faecalis cells remained adhered after a stay in water disinfected with two disinfectants. No significant differences were recorded between the mean densities of E. faecalis cells remained adhered under static condition and those obtained under dynamic condition. Changes in disinfectant concentrations under different experimental conditions have an impact on the detachment of E. faecalis cells adhered to substrates. The same disinfectant could have a different impact on adhered cells in different contexts.

\section{Acknowledgements}

We are grateful to the Head of Corpuscular physic Laboratory of University of Auvergne (France) for providing us materials used in polythene contact angle measurement.

\section{Conflict of Interests}

The authors declare that they have no conflict of interests that could inappropriately influence this work.

\section{References}

Allion A. 2004. Environnement des bactéries et sensibilité aux biocides: Mise au point d'une technique rapide pour déterminer in situ l'efficacité des agents bactéricides. Thèse de Doctorat, École Nationale Supérieure Industries Agricoles et Alimentaires.

American Public Health Association (APHA), 2005. Standard Methods for the Examination of Water and Wastewater. American Public Health Association. Washington, DC, USA, $21^{\text {st }}$ edition.

Beaupoil A, Le Borgne C, Moussa Atto A, Mucig $C$ et Roux A. 2010. Risques sanitaires liés à la réutilisation d'eaux usées traitées pour l'aéroaspersion des espaces verts. Thèse, École des Hautes Études en Santé Publique.
Beech IB and Coutinho CLM. 2003. Biofilms on corroding materials, In Biofilms in Medicine, Industry and Environmental Biotechnology-Characteristics, Analysis and Control, Chapter 8. Edited by Lens P, Moran AP, Mahony $\mathrm{T}$, Stoodley $\mathrm{P}$ and O'Flaherty V.

Beech IB and Sunner J. 2004. Biocorosion: Towards understanding interaction between biofilms and metals. Journal of Current Opinion in Biotechnology. 15:181186.

Boutaleb N. 2007. Étude de la formation des biofilms sur les surfaces de matériaux couramment utilisés dans les canalisations d'eau potable. Thèse de Doctorat, Université de Bretagne-Sud.

Briandet R, Meylheuc T, Maher C and BellonFontaine MN. 1999. Listeria monocytogenes Scott A: Cell Surface Charge, Hydrophobicity, and Electron Donor and Acceptor Characteristics under Different Environmental Growth Conditions. Applied and Environmental Microbiology. 65:53285333.

Coeyrehourcq KL. 2003. Étude de méthodes rapides d'analyse de la structure moléculaire du polyéthylène. Thèse de Doctorat, École des Mines de Paris Spécialité Science et Génie des Matériaux.

Doggett MS. 2000. Characterization of fungal biofilms within a municipal water distribution system. Applied Environmental Microbiology. 66:1249-1251.

Dukam S, Pirion P, et Levi Y. 1995. Modélisation du développement des biomasses bactériennes libres et fixées en réseau de distribution d'eau potable. Dans : Adhésion des microorganismes aux surfaces. M.N. Bellon-Fontaine et J. Fourniat (éds), Paris, 149-160.

Gauthier Y et Isoard P. 1989. L'adhésion des bactéries sur les surfaces, Industries Alimentaires et Agricoles, 106:31-33.

Guillemot G. 2006. Compréhension des mécanismes à l'origine de l'adhésion de 
Saccharomyces cerevisiae sur acier inoxydable-Implications pour l'hygiène des surfaces en industrie agroalimentaire. Thèse de Doctorat, Institut National des Sciences Appliquées de Toulouse.

Hoiby N, Bjarnsholt T, Givskov M, Molin S and Ciofu O. 2010. Antibiotic resistance of bacterial biofilms. International Journal of Antimicrobial Agents. 35:322-332.

Holt G, Krieg NR, Sneath PHA, Staley JT and Williams ST. 2000. Bergey's Manual of Determinative Bacteriology, Lipponcott Williams and Wilkins, Philadelphia, $\mathrm{Pa}$, USA, 9th edition.

Jett B, Huycke M and Gilmore M. 1994. Virulence of enterococci. Clinical Microbiology Reviews. 7(4): 462-478.

Keren I, Kaldalu N, Spoering A, Wang Y and Lewis K. 2004. Persister cells and tolerance to antimicrobials. Federation of European Microbiological Societies Microbiology Letters. 230:13-18.

Klausen M, Gjermansen M, Kreft JU and Tolker-Nielsen T. 2006. Dynamics of development and dispersal in sessile microbial communities: examples from Pseudomonas aeruginosa and Pseudomonas putida model biofilm. Federation of European Microbiological Societies Microbiology Letters. 261:1-11.

Leung CY, Chan YC, Samaranayake LP and Seneviratne CJ. 2012. Biocide resistance of Candida and Escherichia coli biofilms is associated with higher antioxidative capacities. Journal of Hospital Infection. 81:79-86.

Lomander A, Schreuders P, Russek-Cohen E and Ali L. 2004. Evaluation of chlorines' impact on biofilms on scratched stainless steel surfaces. Bioresource Technology. 94(3): 275-283.

Lontsi Djimeli C, Nola M, Tamsa Arfao A, Nandjou Nguéfack RV, Noah Ewoti OV, Nougang ME and Moungang ML. 2013. Effect of disinfectants on adhered Aeromonas hydrophila to polyethylene immersed in water under static and dynamic conditions. International Journal of Research in BioSciences. 2, 33-48.

Lontsi Djimeli C, Tamsa Arfao A, Noah Ewoti OV, Bricheux G, Nola $M$ and SimeNgando T. 2014b. Adhesion of Candida albicans to polythene in Sodium hypochlorite disinfected aquatic microcosm and potential impact of cell surface properties. Current Research in Microbiology and Biotechnology. Vol. 2, No. 5: 479-489.

Lontsi Djimeli C, Tamsa Arfao A, Noah Ewoti $\mathrm{OV}$, Nougang ME, Moungang ML, Bricheux G, Nola M and Sime-Ngando T. 2014a. Mixture of Sodium Hypochlorite and Hydrogen Peroxide on Adhered Aeromonas hydrophila to Solid Substrate in Water: Impact of Concentration and Assessment of the Synergistic Effect. International Journal of Bacteriology. Volume 2014, Article ID 121367.

Manero A and Blanch A. 1999. Identification of Enterococcus spp. With a biochemical key. Applied and Environmental Microbiology. 65(10): 4425-4430.

Marchal N, Bourdon JL and Richard C. 1991. Culture Media For Isolation and Biochemical Identification of Bacteria, Doin, Paris, France.

Mouchet P, Montiel A and Rigal S. 1992. Dégradations physicochimiques de l'eau dans les réseaux de distribution, TSM. L'Eau, vol. 87, pp. 299-306.

Moungang LM, Nola M, Noah Ewoti OV, Nougang ME, Lontsi Djimeli C, Tamsa Arfao A and Nandjou Nguefack RV. 2013a. Assessment of the abundance of Staphylococcus aureus and Listeria monocytogenes adhered on Granitic and Basaltic Rock-Fragments Immersed in Wells, in the Equatorial Region in Cameroon (Central Africa). International Journal of Research in Chemistry and Environment. (3):283-294. 
Moungang LM, Nola M, Nougang ME, Noah Ewoti OV, Chihib NE, Krier F and Servais P. 2013b. Abundance of heterotrophic aerobe bacteria (HAB) adsorbed on Granite, Basalt and Migmatite rock fragments immersed in wells in Central Africa: Temporal variation and assessment of the hierarchical influence of some abiotic factors. International Journal of Research in BioSciences. (2): 13-25.

Noah Ewoti OV, Nola M, Moungang LM, Nougang ME, Krier F and Nour-Eddine C. 2011. Adhesion of Escherichia coli and Pseudomonas aeruginosa on Rock surface in aquatic Microcosm: Assessment of the influence of Dissolved Magnesium Sulfate and Monosodium Phosphate. Research Journal of Environment and Earth Science. 3(4): 364-374.

Ntsama C, Bouttier S, Ramaldes $M$ and Fourniat J. 1995. Influence de la nature chimique des désinfectants sur leur activité vis-à-vis de biofilms de Pseudomonas aeruginosa obtenus en conditions dynamiques. Dans: Adhésion des microorganismes aux surfaces. M.N. Bellon-Fontaine et J. Fourniat (éds), Paris, 282-294.

Parot S. 2007. Biofilms Electroactifs: Formation, Caractérisation et Mécanismes. Thèse de Doctorat, Institut National polytechnique de Toulouse.

Pouneh K. 2009. Formation de biofilm à Pseudomonas aeruginosa: évaluation d'inhibiteurs potentiels du Quorum Sensing. Thèse de Doctorat, Université Paul Sabatier, Toulouse III.

Ratner BD. 1993. Plasma deposition of organic thin film control of film chemistry. American Chemical Society of Polymer Preprints. 34: 643-644.
Ratner BD. 1995. Surface modification of polymers: chemical, biological and surface analytical challenges. Biosensors and Bioelectronics. 10: 797-804.

Rodier J. 2009. L'analyse de l'eau, In Dunod Paris, 9ème Edition.

Rubio C. 2002. Conception des mécanismes d'adhésion des biofilms en milieu marin en vue de la conception de nouveaux moyens de prévention. Thèse de Doctorat, Université Paris, XIII.

Smith K and Hunter IS. 2008. Efficacy of common hospital biocides with biofilms of multi-drug resistant clinical isolates. Journal of Medical Microbiology. 57: 966973.

Suci PA, Mittelman MW, Yu FP and Geesey GG. 1994. Investigation of ciprofloxacin penetration into Pseudomonas aeruginosa biofilms. Antimicrobiological Agents Chemotherapy. 38: 2125-2133.

Van der Kooij D and Hijnen WAM. 1988. Nutritional versatility and growth kinetics of an Aeromonas hydrophila strain isolated from drinking water. Applied and Environmental Microbiology. 54:28422851.

WHO, 2004. Guidelines for drinking water quality. OMS Recommendation éd, Geneva.

Yasuda H, Ajiki Y, Koga T and Yokota T. 1994. Interaction between clarithromycin and biofilms by Staphylococcus epidermidis. Antimicrobiological Agents Chemotherapy. 38:138-141.

Yasuda H, Ajiki Y, Koga T, Kawada H and Yokopat T. 1993. Interaction between biofilms formed by Pseudomonas aeruginosa and clarithromycin. Antimicrobiological Agents Chemotherapy. 37:1749-1755. 